\title{
Karolina Ochocinska
}

Uniwersytet Mikołaja Kopernika, Torun

k.ochocinska@onet.pl; ORCID: 0000-0002-7003-7488

\section{Modele doradztwa inwestycyjnego w dyrektywie MiFID II}

http://dx.doi.org/10.12775/SIT.2018.011

\section{Zmiany wprowadzone dyrektywą MiFID II w zakresie usługi doradztwa inwestycyjnego}

Regulacja działalności firm inwestycyjnych oraz świadczonych przez nie usług przewidziana w dyrektywie $\mathrm{MiFID}^{1}$ oraz powiązanych $\mathrm{z}$ nią aktach prawnych (dyrektywa implementująca MiFID ${ }^{2}$ i rozporządzenie implementujące MiFID $^{3}$ ) zostanie zastąpiona przez dyrektywę

${ }^{1}$ Dyrektywa 2004/39/WE Parlamentu Europejskiego i Rady z dnia 21 kwietnia 2004 r. w sprawie rynków finansowych zmieniająca dyrektywę Rady 85/611/EWG i 93/6/EWG i dyrektywę 2000/12/WE Parlamentu Europejskiego i Rady oraz uchylająca dyrektywę Rady 93/22/EWG (Dz.Urz. WE L 145/ 1 z 30.04.2004 r.; dalej: dyrektywa MiFID).

2 Dyrektywa Komisji 2006/73/WE $z$ dnia 10 sierpnia 2006 r. wprowadzająca środki wykonawcze do dyrektywy 2004/39/WE Parlamentu Europejskiego i Rady w odniesieniu do wymogów organizacyjnych i warunków prowadzenia działalności przez przedsiębiorstwa inwestycyjne oraz pojęć zdefiniowanych na potrzeby tejże dyrektywy (Dz.Urz. UE L 241/26 z 02.09.2006 r.; dalej: dyrektywa implementująca MiFID).

${ }^{3}$ Rozporządzenie Komisji nr 1287/2006 z dnia 10 sierpnia 2006 r. wprowadzające środki wykonawcze do dyrektywy 2004/39/WE Parlamentu Europejskiego i Rady w odniesieniu do zobowiązań przedsiębiorstw inwestycyjnychw zakresie prowadzenia rejestrów, sprawozdań z transakcji, przejrzystości rynkowej, dopuszczania instrumentów finansowych do obrotu oraz pojęć zdefiniowanych 
MiFID II $^{4}$ oraz rozporządzenie MiFIR ${ }^{5}$. Zmiany wejdą w życie od 03.01.2018 $\mathrm{r}^{6}$

Wdrożenie nowych rozwiązań okazało się konieczne ze względu na ujawnione po kryzysie finansowym słabości w funkcjonowaniu i przejrzystości rynków finansowych ${ }^{7}$. Na tle świadczenia usług doradztwa inwestycyjnego źródłem problemów okazały się m.in. zasady wynagradzania firm inwestycyjnych. Odpowiedzią na to zagadnienie jest wprowadzenie przez prawodawcę unijnego rozróżnienia na niezależne oraz inne niż niezależne doradztwo inwestycyjne ${ }^{8}$. Ma to służyć zapobieganiu zjawisku konfliktu interesów firmy inwestycyjnej i jej klienta oraz zwiększeniu poziomu ochrony inwestorów ${ }^{9}$.

na potrzeby tejże dyrektywy (Dz.Urz. UE L 241/26 z 02.09.2006 r.; dalej: rozporządzenie implementujące MiFID).

${ }^{4}$ Dyrektywa Parlamentu Europejskiego i Rady 2014/65/UE z dnia 15 maja 2014 r. w sprawie rynków instrumentów finansowych oraz zmieniająca dyrektywę 2002/92/WE i dyrektywę 2011/61/UE (Dz. Urz. UE L 173/394 z 12.06.2014 r.; dalej: dyrektywa MiFID II).

${ }^{5}$ Rozporządzenie Parlamentu Europejskiego i Rady (UE) nr 600/2014 z dnia 15 maja 2014 r. w sprawie rynków instrumentów finansowych oraz zmieniające rozporządzenie (EU) nr 648/2012 (Dz.Urz. UE L 173/84 z 12.06.2014 r.; dalej: rozporządzenie MiFIR).

${ }^{6}$ Rozporządzenie MiFIR miało być stosowane od 03.01.2017 r. (art. 93 rozporządzenia MiFIR). Termin ten odroczono o rok na mocy Rozporządzenia Parlamentu Europejskiego i Rady (UE) 2016/1033 z dnia 23 czerwca 2016 r. zmieniającego rozporządzenie (UE) $\mathrm{nr}$ 600/2014 w sprawie rynków instrumentów finansowych, rozporządzenie (UE) nr 596/2014 w sprawie nadużyć na rynku oraz rozporządzenie (UE) nr 909/2014 w sprawie usprawnienia rozrachunku papierów wartościowych w Unii Europejskiej i w sprawie centralnych depozytów papierów wartościowych (Dz.Urz. L Nr 175/1 z 30.06.2016 r.). Dyrektywa MiFID II miała zostać zaimplementowana do porządków prawnych państw członkowskich do 03.07.2016 r. na podstawie przepisów obowiązujących od 03.01.2017 r. (art. 93 dyrektywy MiFID II). Daty te uległy przesunięciu o 12 miesięcy na podstawie Dyrektywy Parlamentu Europejskiego i Rady (UE) 2016/1034 z dnia 23 czerwca 2016 r. zmieniającej dyrektywę 2014/65/ /UE w sprawie rynków instrumentów finansowych (Dz.Urz UE L Nr 175/8 z 30.06.2016 r.).

7 Motyw 4 dyrektywy MiFID II.

8 Art. 24 ust. 4 lit. a pkt. i oraz art. 24 ust. 7 dyrektywy MiFID II. J. Dybiński, w: Prawo instrumentów finansowych. System prawa handlowego, Tom 4, red. M. Stec, Warszawa 2016, s. 1406.

${ }^{9}$ Motyw 74 dyrektywy MiFID II. 


\section{Istota doradztwa inwestycyjnego}

Cechą charakterystyczną rynku instrumentów finansowych jest występowanie zjawiska asymetrii informacji między firmą inwestycyjną a jej klientem. Klient, w odróżnieniu od firmy inwestycyjnej, dysponuje ograniczonym zakresem wiedzy na temat natury instrumentów finansowych oraz konsekwencji, jakie wiążą się z dokonaniem inwestycji ${ }^{10}$. W rezultacie stosunek zobowiązaniowy pomiędzy klientem a firmą inwestycyjną opiera się w dużym stopniu na zaufa$n^{n i u^{11}}$. Decyzje inwestycyjne podejmowane przez klientów mogą być $\mathrm{w}$ pewnej mierze determinowane rekomendacjami przekazywanymi przez firmę inwestycyjną $\mathrm{w}$ ramach świadczenia usługi doradztwa inwestycyjnego. Jednak finalne ryzyko inwestycyjne takich działań ponosi klient, który jest stroną stosunków prawnych nawiązywanych $\mathrm{z}$ osobami trzecimi. W ramach usługi doradztwa inwestycyjnego firma inwestycyjna nie gwarantuje bowiem osiągnięcia efektów w postaci skuteczności porady ${ }^{12}$.

Doradztwo inwestycyjne stanowi jedną $z$ usług inwestycyjnych wymienionych w załączniku I sekcji A dyrektywy MiFID II. Przepis art. 4 ust. 1 pkt 4 dyrektywy MiFID II definiuje ją jako świadczenie na rzecz klienta, na jego wniosek albo $z$ inicjatywy firmy inwestycyjnej, osobistej rekomendacji w odniesieniu do jednej lub większej liczby transakcji na instrumentach finansowych.

Usługa doradztwa inwestycyjnego zawsze powinna być świadczona na podstawie umowy ${ }^{13}$. Już na gruncie regulacji przewidzianej w dyrektywie MiFID wyrażono pogląd, zgodnie z którym konieczne jest ustanowienie maksymalnie liberalnych przesłanek konkludentnego zawarcia umowy o doradztwo inwestycyjne. Przepisy ustawy

10 T. Czech, Kryterium odpowiedniego charakteru usługi inwestycyjnej oraz instrumentów finansowych według MiFID, „Przegląd Prawa Handlowego” 2009, nr 7, s. 17.

${ }_{11}$ M. Kurzajewski, Usługi maklerskie, Warszawa 2014, s. 278.

12 P. Zapadka, w: Prawo rynku kapitałowego. Komentarz, red. M. Wierzbowski, L. Sobolewski, P. Wajda, Warszawa 2012, s. 1085.

${ }^{13}$ Zob. art. 25 ust. 5 dyrektywy MiFID II oraz art. 19 ust. 7 dyrektywy MiFID. 
o obrocie instrumentami finansowymi ${ }^{14}$ nie stawiają wymogu co do formy takiej umowy ${ }^{15}$. Umowa o doradztwo inwestycyjne oraz świadczenie firmy inwestycyjnej nie muszą zostać utrwalone na piśmie. W rezultacie nawet krótkotrwały przejaw przekazu, który sugeruje klientowi firmy inwestycyjnej określone zachowanie, może zostać zakwalifikowany jako rekomendacja świadczona w ramach usługi doradztwa inwestycyjnego ${ }^{16}$.

Regulacja umowy o świadczenie usług doradztwa inwestycyjnego przewidziana w ustawie o obrocie instrumentami finansowymi nie jest pełna. W doktrynie wskazuje się na to, że zastosowanie w tym przypadku znajdą przepisy kodeksu cywilnego ${ }^{17}$ o umowie zlecenia $^{18}$. Usługa doradztwa inwestycyjnego może być świadczona na podstawie umowy o charakterze incydentalnym (,pojedyncza porada”), jak i umowy o charakterze okresowym lub ciągłym ${ }^{19}$.

Istotą doradztwa inwestycyjnego jest sformułowanie rekomendacji dokonania odpowiedniej inwestycji, przy czym zalecenie to jest potencjalnie realizowane przez klienta ${ }^{20}$. Treść rekomendacji możne skłaniać do nabycia lub zbycia jednego instrumentu finansowego lub większej ich liczby, albo do dokonania innej czynności wywołującej równoważne skutki, której przedmiotem są instrumenty finansowe, albo powstrzymania się od wykonania takiej czynności ${ }^{21}$.

${ }^{14}$ Ustawa $z$ dnia 29 lipca 2005 r. o obrocie instrumentami finansowymi (tekst jednolity: Dz.U. z 2017 r. poz. 1768 ze zm.; dalej: ustawa o obrocie instrumentami finansowymi).

${ }_{15}$ T. Sójka, Umowa o doradztwo inwestycyjne $w$ obrocie instrumentami finansowymi - zagadnienia podstawowe, „Przegląd Prawa Handlowego” 2014, nr 4 , s. 43.

${ }^{16}$ K. Zacharzewski, w: Prawo instrumentów finansowych, op.cit., s. 1228. Zob. wyrok SA w Warszawie z dnia 6 czerwca 2017 r., I ACa 276/16, niepubl.; wyrok SA w Gdańsku z dnia 23 marca 2016 r., I ACa 951/15, niepubl.

17 Ustawa z dnia 23 kwietnia 1964 r. Kodeks cywilny (tekst jednolity: Dz.U. z 2017 r. poz. 459 ze zm.; dalej: k.c.).

18 T. Sójka, Umowa o doradztwo inwestycyjne, s. 39.

19 A. Chłopecki, M. Dyl, w: System prawa prywatnego, t. 19: Prawo papierów wartościowych, red. A. Szumański, Warszawa 2006, s. 970-971.

${ }^{20}$ Ibidem.

${ }^{21}$ Zob. art 76 ust. 1 ustawy o obrocie instrumentami finansowymi. 


\section{Konflikt interesów na tle doradztwa inwestycyjnego}

$\mathrm{Na}$ tle relacji kontraktowej pomiędzy firmą inwestycyjną a jej klientem mogą pojawiać się konflikty interesów. Pod tym pojęciem rozumie się znane firmie inwestycyjnej okoliczności, które mogą doprowadzić do powstania sprzeczności między interesem firmy inwestycyjnej lub osoby powiązanej $z$ firmą inwestycyjną a obowiązkiem działania w sposób rzetelny, $\mathrm{z}$ uwzględnieniem najlepiej pojętego interesu klienta. Ponadto mogą to być znane firmie inwestycyjnej okoliczności, które prowadzą do powstania sprzeczności między interesami kilku klientów firmy inwestycyjnej ${ }^{22}$.

Konflikt interesów może być spowodowany m.in. zasadami wynagradzania firm inwestycyjnych ${ }^{23}$. Przykładem jest sprzeczność interesów związana $z$ mechanizmem dystrybucji instrumentów finansowych. $Z$ istoty usługi doradztwa inwestycyjnego wynika jej powiązanie $z$ czynnością maklerską przyjęcia i przekazania zlecenia do podmiotu, którego instrumenty finansowe były przedmiotem rekomendacji. W zamian za przekazanie zlecenia nabycia danego instrumentu finansowego firma inwestycyjna otrzymuje od emitenta korzyść w postaci wartości pieniężnej. Jej wysokość odpowiada całości lub części opłaty dystrybucyjnej. W konsekwencji celem firmy inwestycyjnej będzie maksymalizacja zysków z tytułu otrzymywanych opłat dystrybucyjnych poprzez rekomendowanie instrumentów finansowych, których dystrybucją się zajmuje, a które nie zawsze są odpowiednie dla danego klienta ${ }^{24}$.

${ }^{22} \S 23$ ust. 2 Rozporządzenia Ministra Finansów z dnia 24 września 2012 r. w sprawie trybu i warunków postępowania firm inwestycyjnych, banków, o których mowa w art. 70 ust. 2 ustawy o obrocie instrumentami finansowymi, oraz banków powierniczych (Dz.U. z 2012 r. poz. 1078 ze zm.).

${ }^{23}$ Art. 23 ust. 1 dyrektywy MiFID II.

${ }^{24}$ M. Kurzajewski, op.cit., s. 223; T. Sójka, w: Cywilnoprawna ochrona inwestorów korzystajacych $z$ usług maklerskich na rynku kapitałowym, red. T. Sójka, Warszawa 2016, s. 218; R. Mroczkowski, Działalność w zakresie dystrybucji jednostek uczestnictwa funduszy inwestycyjnych $w$ świetle przepi- 
Konflikt interesów firmy inwestycyjnej i klienta ujawnia się też, gdy firma inwestycyjna lub osoba powiązana $z$ firmą inwestycyjną otrzymuje od osoby trzeciej lub osoby, która działa w imieniu osoby trzeciej, wynagrodzenie, prowizje, korzyść pieniężną lub niepieniężną w związku z usługą świadczoną na rzecz klienta. Takie wynagrodzenia, prowizje, korzyści pieniężne lub niepieniężne określane są mianem zachęt (ang. inducements). W charakterze osoby trzeciej lub osoby, która działa w imieniu osoby trzeciej, może wystąpić instytucja oferująca produkty dostępne na rynku. Przykładem może być sytuacja pośredniczenia przez firmę inwestycyjną w sprzedaży jednostek uczestnictwa funduszy inwestycyjnych. Firma inwestycyjna otrzymuje od podmiotu zarządzającego funduszem inwestycyjnym wynagrodzenie uzależnione od wielkości sprzedaży. Wynagrodzenie to stanowi cześć opłaty za zarządzanie pobieranej od nabywcy jednostki uczestnictwa funduszu inwestycyjnego ${ }^{25}$.

Otrzymywane przez firmy inwestycyjne wynagrodzenia oraz zachęty motywują do określonego sposobu wykonywania usługi doradztwa inwestycyjnego ${ }^{26}$. Firma inwestycyjna może preferować usługi podmiotu, który przysparza jej korzyści, bez względu na to, czy towarzyszy temu odpowiednio wysoka jakość usług27. Wybór ocenianych na potrzeby sporządzania rekomendacji instrumentów finansowych nie jest podyktowany działaniem w najlepiej pojętym interesie klienta, lecz chęcią osiągnięcia zysku przez firmę inwestycyjną.

\section{Niezależne doradztwo inwestycyjne}

Wyróżnienie modelu niezależnego doradztwa inwestycyjnego służy do wyeliminowania przyczyn konfliktów interesów pomiędzy firmą

sów prawa polskiego i dyrektywy MiFID, w: Regulacja MiFID. Skutki prawne dla funkcjonowania rynku finansowego, red. E. Rutkowska-Tomaszewska, Wrocław 2014, s. 72.

${ }^{25}$ T. Sójka, w: Cywilnoprawna ochrona inwestorów, s. 154.

${ }^{26}$ Ibidem, s. 153.

${ }^{27}$ M. Kurzajewski, op.cit., s. 174-175. 
inwestycyjną i jej klientem. Niezależność doradztwa inwestycyjnego na gruncie dyrektywy MiFID II postrzegana jest przez pryzmat zasad wynagradzania firm inwestycyjnych.

Niezależność finansowa firmy inwestycyjnej w stosunku do osób trzecich realizowana jest przez zakaz przyjmowania zachęt. Firma inwestycyjna nie może przyjmować ani pobierać wynagrodzenia, prowizji ani jakichkolwiek korzyści pieniężnych lub niepieniężnych, wypłacanych lub przekazywanych przez jakąkolwiek osobę trzecią lub osobę, która działa w imieniu osoby trzeciej, w związku ze świadczeniem usługi doradztwa inwestycyjnego na rzecz klientów ${ }^{28}$. W ramach modelu niezależnego firma inwestycyjna jest wynagradzana bezpośrednio przez klienta. Dzięki takiemu rozwiązaniu usługę doradztwa inwestycyjnego świadczy podmiot niezależny względem instytucji, które oferują produkty dostępne na rynku. W konsekwencji firmy inwestycyjne kierują się potrzebami klientów, a nie wskazaniami instytucji finansowych ${ }^{29}$.

Zakaz otrzymywania zachęt nie dotyczy drobnych korzyści niepieniężnych. Przyjęcie takiej korzyści jest dopuszczalne, jeżeli ma ona na celu zwiększenie jakości usługi świadczonej klientowi oraz nie wpływa negatywnie na przestrzeganie przez firmę inwestycyjną jej obowiązku działania zgodnie $z$ najlepiej pojętym interesem klienta ${ }^{30}$. Informacji na temat tego, jak rozumieć wskazane w dyrektywie MiFID II dopuszczalne drobne korzyści, dostarcza projekt dyrektywy delegowanej MiFID II ${ }^{31}$. Pod tym pojęciem mieści się przekazywanie

${ }^{28}$ Art. 24 ust. 7 lit. b dyrektywy MiFID II.

${ }^{29}$ P. Tereszkiewicz, Obowiązki informacyjne $w$ umowach o usługi finansowe, Warszawa 2014, s. 228-229.

30 Art. 24 ust. 7 lit. b zd. 2 dyrektywy MiFID II.

${ }^{31}$ Art. 12 ust. 3 projektu Dyrektywy Delegowanej Komisji (UE) C(2016) 2031 z dnia 7.4.2016 r. uzupełniającej dyrektywę Parlamentu Europejskiego i Rady 2014/65/UE w odniesieniu do zabezpieczenia instrumentów finansowych i środków pieniężnych należących do klientów, zobowiązań w zakresie zarządzania produktami oraz zasad mających zastosowanie do oferowania lub przyjmowania wynagrodzeń, prowizji bądź innych korzyści pieniężnych lub niepieniężnych (dalej: projekt dyrektywy delegowanej MiFID II), https:// ec.europa.eu/transparency/regdoc/rep/3/2016/PL/3-2016-2031-PL-F1-1. PDF (dostęp: 27.09.2017 r.). 
na rzecz firmy inwestycyjnej m.in. informacji lub dokumentów na temat instrumentu finansowego lub usługi inwestycyjnej ${ }^{32}$.

Dotychczas przepisy zarówno na poziomie krajowym, jak i unijnym nie regulowały problemu zakresu instrumentów finansowych, który powinien być przedmiotem analizy firmy inwestycyjnej. Firma inwestycyjna korzystała $z$ pełnej swobody w tej kwestii ${ }^{33}$. Taki stan rzeczy był krytykowany ze względu na możliwość wstąpienia konfliktu interesów firmy inwestycyjnej i jej klienta, nieobiektywności doradztwa lub niepoprawności w wyborze rekomendowanych instrumentów finansowych ${ }^{34}$. Regulacja dyrektywy MiFID II przewiduje obowiązek oceny przez firmę inwestycyjną zróżnicowanych pod względem rodzaju i emitentów instrumentów finansowych dostępnych na rynku. Instrumenty finansowe, brane pod uwagę na potrzeby oceny, nie mogą ograniczać się do tych emitowanych lub dostarczanych przez samą firmę inwestycyjną lub przez podmioty blisko $z$ nią powiązane ${ }^{35}$. Zgodnie $z$ stanowiskiem ESMA $^{36}$ w sytuacji, gdy firma inwestycyjna, która świadczy usługę doradztwa inwestycyjnego w ramach modelu niezależnego, rekomenduje swoim klientom instrumenty finansowe emitowane lub dostarczane przez samą firmę lub przez podmioty blisko $z$ nią powiązane, może wystąpić konflikt ze statusem niezależnego doradztwa inwestycyjnego. W przypadku, gdy takie działanie firmy inwestycyjnej można określić jako rutynowe, ESMA oczekuje, że firma inwestycyjna dokona dokładnej wewnętrznej oceny, czy i w jakim stopniu interesy klientów są lub mogą być naruszone. Wewnętrzna ocena powinna zawierać informacje na temat tego, w jaki sposób firma inwestycyjna oceniła i porównała instrumenty finansowe. Należy również jasno określić czynniki, na podstawie których opiera się ocena oraz które z nich wpłynęły na jej wynik ${ }^{37}$.

32 Art. 12 ust. 3 lit. a projektu dyrektywy delegowanej MiFID II.

${ }_{33}$ M. Kurzajewski, op.cit., s. 288-289.

${ }^{34}$ P. Tereszkiewicz, op.cit., s. 223.

${ }^{35}$ Art. 24 ust. 7 lit. a dyrektywy MiFID II.

${ }^{36}$ ESMA, Questions and Answers On MiFID II and MiFIR investor protection topics, s. 37 https://www.esma.europa.eu/sites/default/files/library/esma3543-349_mifid_ii_qas_on_investor_protection_topics.pdf (dostęp: 27.09.2017 r.). 37 Ibidem. 


\section{Inne niż niezależne doradztwo inwestycyjne}

W sytuacji, gdy doradztwo inwestycyjne nie spełnia wymogów przewidzianych dla niezależnego doradztwa inwestycyjnego, stanowi inne niż niezależne doradztwo inwestycyjne. Prawodawca unijny nie definiuje tego pojęcia i dlatego konieczne jest posługiwanie się nazwą opisową. Świadczenie usługi doradztwa inwestycyjnego w ramach tego modelu nie zwalnia firmy inwestycyjnej z obowiązku przestrzegania pozostałych postanowień dyrektywy MiFID II w zakresie ochrony klientów. Należy tutaj wskazać m.in zakaz przyjmowania zachęt oraz ogólny obowiązek rzetelności ${ }^{38}$.

Firma inwestycyjna nie może wypłacać lub przyjmować jakichkolwiek opłat bądź prowizji lub zapewniać bądź czerpać jakichkolwiek korzyści niepieniężnych związanych ze świadczeniem usług inwestycyjnych lub usługi dodatkowej jakiejkolwiek stronie lub przez jakąkolwiek stronę, z wyjątkiem klienta lub osoby, która działa w imieniu klienta ${ }^{39}$.

Wyjątek od zakazu przyjmowania zachęt stanowią płatności lub korzyści, które prowadzą do poprawy jakości usługi świadczonej klientowi ${ }^{40}$. Takie płatności lub korzyści nie mogą mieć negatywnego wpływu na przestrzeganie przez firmę inwestycyjną jej obowiązku uczciwego, sprawiedliwego i profesjonalnego działania zgodnie $z$ najlepiej pojętym interesem klienta ${ }^{41}$. Poprawa jakości usługi świadczonej klientowi może polegać na świadczeniu usługi dodatkowej lub usługi wyższego stopnia na rzecz klienta. Taka usługa musi być proporcjonalna do poziomu otrzymanych zachęt. Jako jeden z przykładów wskazać można świadczenie usługi zależnego doradztwa inwestycyjnego, która obejmuje szeroki zakres instrumentów

\footnotetext{
38 T. Sójka, w: Cywilnoprawna ochrona inwestorów, s. 219-220.

39 Art. 24 ust. 9 dyrektywy MiFID II.

${ }^{40}$ Art. 24 ust. 9 lit. a dyrektywy MiFID II.

${ }^{41}$ Art. 24 ust. 9 lit. b dyrektywy MiFID II.
} 
finansowych ${ }^{42}$. Zakazem wypłacania lub przyjmowania zachęt nie są objęte płatności lub korzyści niezbędne do świadczenia usług inwestycyjnych ${ }^{43}$.

Mniej restrykcyjna niż w przypadku niezależnego doradztwa inwestycyjnego regulacja dopuszczalności przyjmowania zachęt umożliwia utrzymanie bezpłatnego charakteru usługi. Skutkuje to obniżeniem jej jakości, ale równocześnie pozwala na zapewnienie dostępu do bezpłatnego doradztwa inwestycyjnego dla klientów nieprofesjonalnych ${ }^{44}$.

\section{Obowiązki firmy inwestycyjnej w stosunku do klienta}

Na firmie inwestycyjnej ciąży ogólny obowiązek rzetelności. U jego podstaw leży założenie, że firma inwestycyjna zobowiązana jest działać uczciwie, sprawiedliwie i profesjonalnie, zgodnie $z$ najlepiej pojętym interesem klienta ${ }^{45}$. Praktyczna ocena kategorii najlepiej pojętego interesu klienta nawiązuje do występującego na tle prowadzenia cudzej sprawy bez zlecenia (art. 752 k.c.) kryterium obowiązku prowadzenia cudzej sprawy tak, jakby życzył sobie tego domini negotii. Obowiązek liczenia się $z$ najlepiej pojętym interesem klienta nakłada na firmę inwestycyjną w fazie wykonywania zobowiązań (oraz w fazie przedkontraktowej) obowiązek działania z korzyścią dla klienta, zgodnie $z$ jego prawdopodobną wolą i z zachowaniem przy prowadzeniu sprawy zawodowej staranności ${ }^{46}$.

Obowiązek rzetelności jest podstawowym mechanizmem, który ma na celu ograniczenie arbitralności firmy inwestycyjnej w korzystaniu z przyznanej jej swobody określania sposobu wykonywania usługi $^{47}$. Zostaje on uzupełniony i skonkretyzowany poprzez nało-

\footnotetext{
42 Art. 11 ust. 2 projektu dyrektywy delegowanej MiFID II.

${ }^{43}$ Art. 24 ust. 9 dyrektywy MiFID II.

${ }^{44}$ T. Sójka, w: Cywilnoprawna ochrona inwestorów, s. 218-219.

${ }^{45}$ Art. 24 ust. 1 dyrektywy MiFID II.

${ }^{46}$ K. Zacharzewski, w: Prawo rynku kapitałowego. Komentarz, red. M. Wierzbowski, L. Sobolewski, P. Wajda, s. 1156-1157.

${ }^{47}$ T. Sójka, w: Cywilnoprawna ochrona inwestorów, s. 153.
} 
żenie na firmy inwestycyjne dalszych obowiązków wobec klienta, zarówno w ramach relacji kontraktowej, jak i w stadium przedkontraktowym ${ }^{48}$.

Tendencja rozszerzania obowiązków firm inwestycyjnych w stosunku do klienta, w tym obowiązków informacyjnych w zakresie usług finansowych, widoczna była już na gruncie dyrektywy MiFID. Obowiązki te przybierały postać szczegółowych wskazówek co do przedmiotu i zakresu informacji, a także określenia etapu wzajemnych stosunków, na którym taka informacja powinna być udzielona $^{49}$. W dyrektywie MiFID II wprowadzono nowe obowiązki w związku z wyróżnieniem niezależnego doradztwa inwestycyjnego.

Firma inwestycyjna obowiązana jest do udzielenia klientowi informacji na temat tego, czy usługa doradztwa będzie świadczona w ramach modelu niezależnego oraz czy opiera się na szerokiej czy też bardziej ograniczonej analizie różnych rodzajów instrumentów finansowych. Informacja musi wskazywać na to, czy analizowane instrumenty finansowe ograniczają się do tych emitowanych lub dostarczanych przez podmioty blisko powiązane $z$ firmą inwestycyjną. Ponadto firma inwestycyjna obowiązana jest poinformować o tym, czy zapewnia okresową ocenę odpowiedniości instrumentów finansowych rekomendowanych klientowi ${ }^{50}$.

Kolejny obowiązek informacyjny związany jest $\mathrm{z}$ regulacjami w zakresie dopuszczalności przyjmowania zachęt przez firmy inwestycyjne. W sytuacji świadczenia doradztwa inwestycyjnego w modelu innym niż niezależny konieczne jest przekazanie klientowi informacji o otrzymanych zachętach oraz o ich wysokości ${ }^{51}$. Natomiast w przypadku usługi niezależnego doradztwa inwestycyjnego, w któ-

48 P. Tereszkiewicz, op.cit., s. 171.

49 E. Rutkowska-Tomaszewska, Obowiazki informacyjne firm inwestycyjnych świadczacych usługi $w$ ramach działalności maklerskiej wobec klientów detalicznych, w: Regulacja MiFID, s. 78-79. Zob. art. 19 ust. 3 dyrektywy MiFID i art. 24 ust. 4 dyrektywy MiFID II, które dotyczą obowiązku dostarczenia klientowi informacji na temat firmy inwestycyjnej oraz świadczonych przez nią usług, instrumentów finansowych i proponowanych strategii inwestycyjnych, wszystkich kosztów i powiązanych opłat.

50 Art. 24 ust. 4 lit. a dyrektywy MiFID II.

${ }^{51}$ Art. 24 ust. 9 dyrektywy MiFID II. 
rej ramach przyjmowanie zachęt jest niedopuszczalne, informacja dotyczy otrzymanych drobnych korzyści niepieniężnych. Stanowią one wyjątek od zakazu przyjmowania zachęt ${ }^{52}$.

Dyrektywa MiFID II przewiduje obowiązek zwrotu na rzecz klientów zachęt otrzymanych przez firmy inwestycyjne. Firmy inwestycyjne są zobowiązane do ustanowienia i wdrażania zasad w celu zagwarantowania, że zachęty otrzymane w związku ze świadczeniem usług w zakresie niezależnego doradztwa inwestycyjnego zostaną przypisane i przekazane każdemu indywidualnemu klientowi ${ }^{53}$.

Firma inwestycyjna obowiązana jest też do podejmowania działań w celu uzyskania wiadomości na temat klienta, aby ustalić istotne elementy jego indywidualnej sytuacji pod kątem inwestycji na rynku instrumentów finansowych (zasada „poznaj swojego klienta”) ${ }^{54}$. Zakres przedmiotowy wymaganych informacji obejmuje wiedzę klienta, a więc posiadane przez niego wiadomości na temat produktów i usług inwestycyjnych oraz celów inwestycyjnych. Ponadto ich zakres zawiera doświadczenie klienta, czyli historię dotychczasowych kontaktów $\mathrm{z}$ rynkiem instrumentów finansowych ${ }^{55}$.

Rekomendowane klientowi lub potencjalnemu klientowi usługi inwestycyjne i instrumenty finansowe winny być dostosowane do jego tolerancji ryzyka i zdolności ponoszenia strat ${ }^{56}$. Wypełnieniu tego obowiązku służą wiadomości uzyskane od klienta. Rekomendowana transakcja powinna realizować cele inwestycyjne danego klienta np. co do oczekiwanych przychodów. Ponadto powinna charakteryzować się tym, że klient jest w stanie ponieść i zrozumieć wszelkie związane z nią ryzyka inwestycyjne. Gdy transakcja spełnia powyższe kryteria, może zostać uznana za odpowiednią dla danego klienta ${ }^{57}$.

52 Art. 24 ust. 7 lit. b dyrektywy MiFID II.

53 Art. 12 ust. 1 projektu dyrektywy delegowanej MiFID II, motyw 73 dyrektywy MiFID II.

${ }^{54}$ Zob. art. 25 ust. 2,3 dyrektywy MiFID II oraz art. 19 ust. 4 dyrektywy MiFID. T. Czech, op.cit., s. 17.

55 Ibidem, s. 21.

56 Art. 25 ust. 2 dyrektywy MiFID II.

57 T. Czech, op.cit., s. 22. 


\section{Konsekwencje wyróżnienia niezależnego doradztwa inwestycyjnego}

Doradztwo inwestycyjne można określić jako jeden $z$ kluczowych instrumentów wspierania roztropnego udziału inwestorów w rynku kapitałowym. Usługa ta podlegała szerokiej regulacji już na gruncie dyrektywy MiFID ${ }^{58}$. Wprowadzone przez dyrektywę MiFID II wyróżnienie niezależnego doradztwa inwestycyjnego prowadzi do większej ochrony interesu klienta oraz pozwala na pełniejszą realizację ogólnego obowiązku rzetelności firmy inwestycyjnej. Ponadto wyraźne odróżnienie niezależnego doradztwa inwestycyjnego od innego niż niezależne doradztwa inwestycyjnego pozwala na przezwyciężenie panującego wśród klientów firm inwestycyjnych mylnego przekonania, zgodnie $z$ którym usługi doradztwa inwestycyjnego są świadczone bezpłatnie ${ }^{59}$.

W ramach modelu niezależnego doradztwa inwestycyjnego firma świadcząca usługi inwestycyjne poddana zostaje dalej idącym wymogom. Konieczność analizy zróżnicowanego katalogu instrumentów finansowych, na potrzeby sporządzenia rekomendacji, rzutuje na ocenę należytej staranności firmy inwestycyjnej (art. 355 k.c.) oraz jakości świadczenia (art. 357 k.c.). Ponadto postanowienia dyrektywy MiFID II wpływają na interpretację wykazanych w art. 354 k.c. reguł wykonania zobowiązania.

Wyróżnienie niezależnego doradztwa inwestycyjnego wpływa na ocenę prawidłowości należytego wykonania zobowiązania firmy inwestycyjnej. Firma inwestycyjna ponosi odpowiedzialność odszkodowawczą wobec klienta, jeżeli w wyniku niewykonania lub nienależytego wykonania zobowiązania wyrządziła klientowi szkodę

58 T. Sójka, w: Prawo rynku kapitałowego. Komentarz, red. T. Sójka, Warszawa 2015, s. 924.

59 P. Tereszkiewicz, op.cit., s. 224; J. Morbatio, Za rok fundusze będa nie do poznania, „Parkiet” http://www.parkiet.com/Fundusze-inwestycyjne-TFI/ 302139974-Za-rok-fundusze-beda-nie-do-poznania.html?template=restricted (dostęp: 27.09.2017 r.). 
(art. 471 k.c.). Rekomendowana w ramach usługi doradztwa inwestycyjnego transakcja nie daje gwarancji osiągnięcia przez inwestora korzystnych rezultatów. Prawidłowość należytego wykonania zobowiązania przez firmę inwestycyjną podlega obiektywnej oce$n^{n i{ }^{60}}$. Odpowiedzialność firmy inwestycyjnej może zaktualizować się w przypadku nieprzeanalizowania na potrzeby sporządzanej rekomendacji odpowiednio zróżnicowanego katalogu instrumentów finansowych. Ponadto przykładem nienależytego wykonania zobowiązania przez firmę inwestycyjną jest sporządzenie rekomendacji, która nie uwzględnia indywidualnej sytuacji klienta. Takie działanie może wynikać z niewywiązania się przez firmę inwestycyjną $z$ obowiązku uzyskania informacji na temat klienta. Prowadzi to do konieczności oceny, czy i w jakim stopniu klient przyczynił się do powstania lub zwiększenia szkody, np. poprzez podanie firmie inwestycyjnej niepełnych, niedokładnych lub nieaktualnych informacji (art. 362 k.c.) ${ }^{61}$.

\section{STRESZCZENIE}

Modele doradztwa inwestycyjnego w dyrektywie MiFID II

Artykuł porusza problematykę zmian wprowadzonych dyrektywą MiFID II $\mathrm{w}$ zakresie usługi doradztwa inwestycyjnego. Zgodnie $\mathrm{z}$ nową regulacją usługa doradztwa inwestycyjnego może być świadczona przez firmę inwestycyjną w sposób niezależny albo inny niż niezależny. Celem artykułu jest wskazanie przyczyn stojących za wprowadzeniem dwóch modeli doradztwa inwestycyjnego, w tym omówienie zjawiska konfliktu interesów firmy inwestycyjnej i jej klienta. Ponadto zaprezentowane są dwa modele, w ramach których może być świadczona usługa doradztwa inwestycyjnego oraz konsekwencje, jakie niesie ze sobą nowa regulacja.

Słowa kluczowe: doradztwo inwestycyjne; MiFID II; niezależne doradztwo inwestycyjne

${ }^{60}$ K. Zacharzewski, w: Prawo instrumentów finansowych, s. 1239.

${ }^{61}$ T. Czech, op,cit., s. 23. 


\section{SUMMARY}

Models of investment advice under the MiFID II directive

The article discusses changes brought by Markets in Financial Instruments Directive II (MiFID II) in the area of investment advisory services. According to the new regulation, investment advice can be provided by an investment company on an independent and non-independent basis. The aim of the article is to point out the reasons behind the introduction of two models of investment advice, including discussing the conflicts of interest of an investment company and its client. In addition, two models of investment advice and the consequences of the new regulation will be presented.

Keywords: investment advice; MiFID II; independent investment advice

\section{BIBLIOGRAFIA}

Chłopecki A., Dyl M., w: System prawa prywatnego, t. 19: Prawo papierów wartościowych, red. A. Szumański, Warszawa 2006.

Czech T., Kryterium odpowiedniego charakteru usługi inwestycyjnej oraz instrumentów finansowych wedtug MiFID, „Przegląd Prawa Handlowego” 2009, nr 7.

Dybiński J., w: Prawo instrumentów finansowych. System prawa handlowego, Tom 4, red. M. Stec, Warszawa 2016.

Kurzajewski M., Usługi maklerskie, Warszawa 2014.

Morbatio J., Za rok fundusze będa nie do poznania, „Parkiet” http: / /www. parkiet.com/Fundusze-inwestycyjne-TFI/302139974-Za-rok-funduszebeda-nie-do-poznania.html?template=restricted (dostęp: 27.09.2017 r.).

Mroczkowski R., Działalność w zakresie dystrybucji jednostek uczestnictwa funduszy inwestycyjnych $w$ świetle przepisów prawa polskiego i dyrektywy MiFID, w: Regulacja MiFID. Skutki prawne dla funkcjonowania rynku finansowego, red. E. Rutkowska-Tomaszewska, Wrocław 2014.

Rutkowska-Tomaszewska E., Obowiazki informacyjne firm inwestycyjnych świadczacych usługi $w$ ramach działalności maklerskiej wobec klientów detalicznych, w: Regulacja MiFID. Skutki prawne dla funkcjonowania rynku finansowego, red. E. Rutkowska-Tomaszewska, Wrocław 2014.

Sójka T., Umowa o doradztwo inwestycyjne $w$ obrocie instrumentami finansowymi - zagadnienia podstawowe, „Przegląd Prawa Handlowego" 2014, nr 4. 
Sójka T., w: Cywilnoprawna ochrona inwestorów korzystajacych z usług maklerskich na rynku kapitałowym, red. T. Sójka, Warszawa 2016.

Sójka T., w: Prawo rynku kapitałowego. Komentarz, red. T. Sójka, Warszawa 2015.

Tereszkiewicz P., Obowiązki informacyjne $w$ umowach o usługi finansowe, Warszawa 2014.

Zacharzewski K., w: Prawo instrumentów finansowych. System prawa handlowego, Tom 4, red. M. Stec, Warszawa 2016.

Zacharzewski K., w: Prawo rynku kapitałowego. Komentarz, red. M. Wierzbowski, L. Sobolewski, P. Wajda, Warszawa 2012.

Zapadka P., w: Prawo rynku kapitałowego. Komentarz, red. M. Wierzbowski, L. Sobolewski, P. Wajda, Warszawa 2012. 